\title{
Systematic investigation of trigonal-bipyramidal cyanide-bridged clusters of the first row transition metals
}

\author{
Mikhail Shatruk, Kristen Chambers, Andrey V. Prosvirin, Kim R. Dunbar* \\ Department of Chemistry, Texas A\&M University, College Station, Texas 77842-3012
}

\begin{abstract}
RECEIVED DATE (automatically inserted by publisher); E-mail: dunbar@mail.chem.tamu.edu
\end{abstract}

\section{Supporting Information}

Page

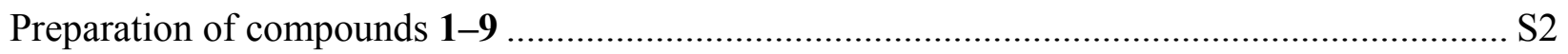

Figure S1. Magnetic properties of compounds 1-3, 10, and 11 ...................................... S6

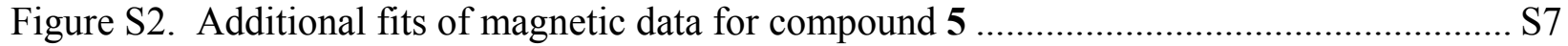

Figure S3. Field dependent magnetization for sample 7a............................................... S8

Figure S4. Reduced magnetization for compound 9 ..................................................... S8

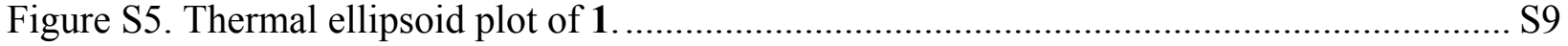

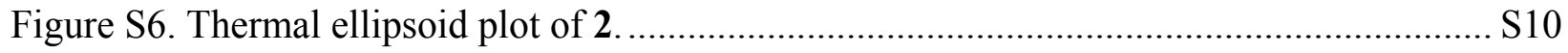

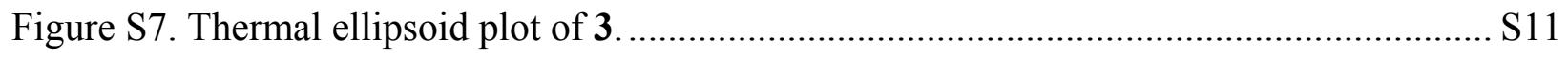

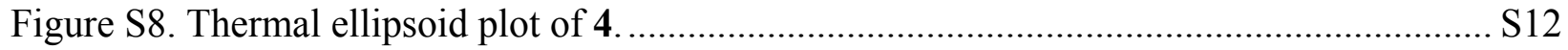

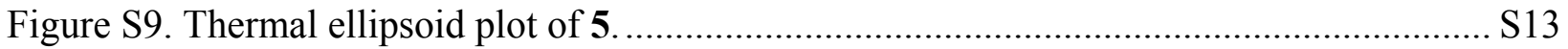

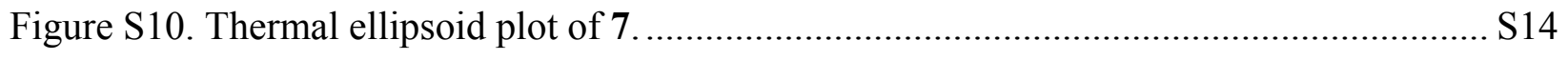

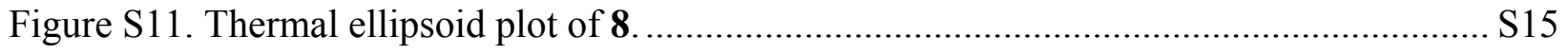

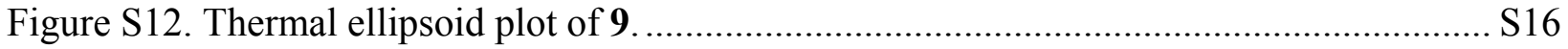

Table S1. Metal-to-ligand bond distances $(\AA)$ in the crystal structures of compounds 1-9...... S17 


\section{Preparation of compounds 1-9}

Starting materials. Commercially available 3,4,7,8-tetramethyl-1,10-phenanthroline (tmphen; Lancaster), 18-crown-6, $\mathrm{K}_{3}\left[\mathrm{Cr}(\mathrm{CN})_{6}\right]$ (Aldrich), $\mathrm{K}_{3}\left[\mathrm{Co}(\mathrm{CN})_{6}\right]$ (Pfaltz \& Bauer) (TBA) $)_{3}\left[\mathrm{Fe}(\mathrm{CN})_{6}\right]$ (TBA = tetrabutylammonium; Fluka), $\mathrm{Mn}\left(\mathrm{ClO}_{4}\right) \cdot x \mathrm{H}_{2} \mathrm{O}, \mathrm{Mn}(\mathrm{OAc})_{2} \cdot 4 \mathrm{H}_{2} \mathrm{O}$ (Aldrich), anhydrous $\mathrm{CrCl}_{2}, \mathrm{Co}\left(\mathrm{NO}_{3}\right)_{2} \cdot 6 \mathrm{H}_{2} \mathrm{O}$ (Strem), $\mathrm{CoCl}_{2} \cdot 6 \mathrm{H}_{2} \mathrm{O}, \mathrm{Ni}(\mathrm{OAc})_{2} \cdot 4 \mathrm{H}_{2} \mathrm{O}, \mathrm{Zn}(\mathrm{OAc})_{2} \cdot 2 \mathrm{H}_{2} \mathrm{O}$ (Fisher) were used as received. Acetonitrile was dried over $3 \AA$ molecular sieves and distilled prior to use. Methanol was of the ACS reagent grade and was used as received (EM Science).

$\mathrm{Cr}_{2}\left(\mathrm{O}_{2} \mathrm{CCF}_{3}\right)_{4} \cdot 2 \mathrm{THF}$ was prepared by reacting $\mathrm{CrCl}_{2}$ and $\mathrm{CF}_{3} \mathrm{COONa}$ in stoichiometric ratio in refluxing THF for $6 \mathrm{~h}$. The solution was filtered and evaporated to dryness. The obtained purple solid was extracted with toluene. The solution was filtered, and the solvent was removed in vacuo to obtain the final product.

$\left[\mathbf{M n}(\mathbf{t m p h e n})_{2}\right]_{3}\left[\mathbf{C o}(\mathbf{C N})_{6}\right]_{2}$ (1). A solution of $[(18 \text {-crown- } 6) \mathrm{K}]_{3}\left[\mathrm{Co}(\mathrm{CN})_{6}\right]$ was prepared by stirring $150 \mathrm{mg}(0.451 \mathrm{mmol}) \mathrm{K}_{3}\left[\mathrm{Co}(\mathrm{CN})_{6}\right]$ and $318 \mathrm{mg}(1.20 \mathrm{mmol})$ 18-crown-6 in $100 \mathrm{~mL}$ acetonitrile for $24 \mathrm{~h}$ and filtering the obtained solution to remove the excess of $\mathrm{K}_{3}\left[\mathrm{Co}(\mathrm{CN})_{6}\right]$. The other solution was prepared by combining $14.5 \mathrm{mg}(0.040 \mathrm{mmol}) \mathrm{Mn}\left(\mathrm{ClO}_{4}\right)_{2} \cdot \mathrm{xH}_{2} \mathrm{O}(\mathrm{x} \approx 6)$ with $18.9 \mathrm{mg}(0.080 \mathrm{mmol})$ tmphen in $10 \mathrm{~mL}$ acetonitrile. After the mixture had been stirred for $30 \mathrm{~min}$, a clear pale yellow solution was obtained. To this solution was quickly added $10 \mathrm{~mL}$ of the $\left[\mathrm{Co}(\mathrm{CN})_{6}\right]^{3-}$ solution, and the mixture was left undisturbed for 5 days. After this period of time, clear light yellow needle-like crystals formed at the bottom of the vial. They were filtered, washed with acetonitrile $(2 \times 20 \mathrm{~mL})$, and dried in vacuo. Yield $-9.8 \mathrm{mg}(33 \%)$. Elemental analysis indicated the presence of interstitial water molecules. Calcd. for $\mathrm{Mn}_{3} \mathrm{Co}_{2} \mathrm{O}_{13} \mathrm{~N}_{24} \mathrm{C}_{108} \mathrm{H}_{122}$ $\left(1 \cdot 13 \mathrm{H}_{2} \mathrm{O}\right): \mathrm{O}, 9.26 ; \mathrm{N}, 14.97$; C, 57.71; H, 5.48; Found: O, 9.27; N, 14.78; C, 57.74; H, 5.04\%. IR (Nujol), $v(\mathrm{C} \equiv \mathrm{N}), \mathrm{cm}^{-1}: 2165,2154,2145,2131$.

$\left[\mathbf{C o}(\text { tmphen })_{2}\right]_{3}\left[\mathbf{C o}(\mathbf{C N})_{6}\right]_{2}$ (2). A solution of $\left[(18 \text {-crown-6)K }]_{3}\left[\mathrm{Co}(\mathrm{CN})_{6}\right]\right.$ was prepared by stirring $150 \mathrm{mg}(0.451 \mathrm{mmol}) \mathrm{K}_{3}\left[\mathrm{Co}(\mathrm{CN})_{6}\right]$ and $318 \mathrm{mg}(1.20 \mathrm{mmol}) 18$-crown-6 in $100 \mathrm{~mL}$ methanol for $2 \mathrm{~h}$ and filtering the obtained solution to remove the excess of $\mathrm{K}_{3}\left[\mathrm{Co}(\mathrm{CN})_{6}\right]$. The other solution was prepared by combining $11.7 \mathrm{mg}(0.040 \mathrm{mmol}) \mathrm{Co}\left(\mathrm{NO}_{3}\right)_{2} \cdot 6 \mathrm{H}_{2} \mathrm{O}$ with $20.1 \mathrm{mg}$ ( $0.085 \mathrm{mmol})$ tmphen in $10 \mathrm{~mL}$ methanol. After the mixture had been stirred for $30 \mathrm{~min}$, a clear light orange solution was obtained. To this solution was quickly added $10 \mathrm{~mL}$ of the $\left[\mathrm{Co}(\mathrm{CN})_{6}\right]^{3-}$ solution, and the mixture was left undisturbed for 2 days. After this period of time, clear orange needle-like crystals formed at the bottom of the vial. They were filtered, washed with methanol 
$(2 \times 20 \mathrm{~mL})$, and dried in vacuo. Yield - $27.5 \mathrm{mg}(83 \%)$. Elemental analysis indicated the presence of interstitial water molecules. Calcd. for $\mathrm{Co}_{5} \mathrm{O}_{19} \mathrm{~N}_{24} \mathrm{C}_{108} \mathrm{H}_{134}\left(\mathbf{2} \cdot 19 \mathrm{H}_{2} \mathrm{O}\right): \mathrm{O}, 12.84 ; \mathrm{N}$,

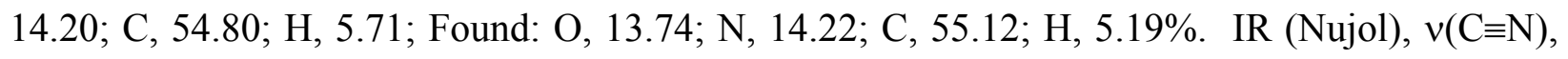
$\mathrm{cm}^{-1}: 2167,2157,2148,2130,2125$.

$\left[\mathbf{N i}(\text { tmphen })_{2}\right]_{3}\left[\mathbf{C o}(\mathbf{C N})_{6}\right]_{2}(3)$. An acetonitrile solution of $\left[(18 \text {-crown-6)K }]_{3}\left[\mathrm{Co}(\mathrm{CN})_{6}\right]\right.$ was prepared as described above for compound 1. The other solution was prepared by combining $10.3 \mathrm{mg}(0.040 \mathrm{mmol}) \mathrm{Ni}(\mathrm{OAc})_{2} \cdot 4 \mathrm{H}_{2} \mathrm{O}$ with $20.1 \mathrm{mg}(0.085 \mathrm{mmol})$ tmphen in $10 \mathrm{~mL}$ acetonitrile. After the mixture had been stirred for $30 \mathrm{~min}$, a clear pale purple solution was obtained. To this solution was quickly added $10 \mathrm{~mL}$ of the $\left[\mathrm{Co}(\mathrm{CN})_{6}\right]^{3-}$ solution, and the mixture was left undisturbed for 2 days. After this period of time, clear purple block-shaped crystals formed at the bottom of the vial. They were filtered, washed with acetonitrile $(2 \times 20 \mathrm{~mL})$, and dried in vacuo. Yield - $17.0 \mathrm{mg}(52 \%)$. Elemental analysis indicated the presence of interstitial water molecules. Calcd. for $\mathrm{Ni}_{3} \mathrm{Co}_{2} \mathrm{O}_{23} \mathrm{~N}_{24} \mathrm{C}_{108} \mathrm{H}_{142}\left(3 \cdot 23 \mathrm{H}_{2} \mathrm{O}\right)$ : O, 15.11; N, 13.80; C, 53.23; H, 5.88; Found: O, 15.16; N, 13.79; C, 53.77; H, 5.38\%. IR (Nujol), v(C $\equiv \mathrm{N}), \mathrm{cm}^{-1}: 2174,2164$, 2154, 2127, 2123.

$\left[\mathrm{Zn}(\mathbf{t m p h e n})_{2}\right]_{3}\left[\mathbf{C o}(\mathbf{C N})_{6}\right]_{2}$ (4). An acetonitrile solution of $\left[(18 \text {-crown-6)K }]_{3}\left[\mathrm{Co}(\mathrm{CN})_{6}\right]\right.$ was prepared as described above for compound 1. The other solution was prepared by combining 8.8 $\mathrm{mg}(0.040 \mathrm{mmol}) \mathrm{Zn}(\mathrm{OAc})_{2} \cdot 2 \mathrm{H}_{2} \mathrm{O}$ with $20.1 \mathrm{mg}(0.085 \mathrm{mmol})$ tmphen in $10 \mathrm{~mL}$ acetonitirle. After the mixture had been stirred for $30 \mathrm{~min}$, a clear colorless solution was obtained. To this solution was quickly added $10 \mathrm{~mL}$ of the $\left[\mathrm{Co}(\mathrm{CN})_{6}\right]^{3-}$ solution, and the mixture was left for 4 days. After this period of time, clear colorless block-shaped crystals formed at the bottom of the vial. They were filtered, washed with acetonitrile $(2 \times 20 \mathrm{~mL})$, and dried in vacuo. Yield -14.5 $\mathrm{mg}(46 \%)$. Elemental analysis indicated the presence of interstitial water molecules. Calcd. for $\mathrm{Zn}_{3} \mathrm{Co}_{2} \mathrm{O}_{18} \mathrm{~N}_{24} \mathrm{C}_{108} \mathrm{H}_{132}\left(4 \cdot 18 \mathrm{H}_{2} \mathrm{O}\right): \mathrm{O}, 12.19 ; \mathrm{N}, 14.22 ; \mathrm{C}, 54.85 ; \mathrm{H}, 5.63 ;$ Found: O, 12.02; N,

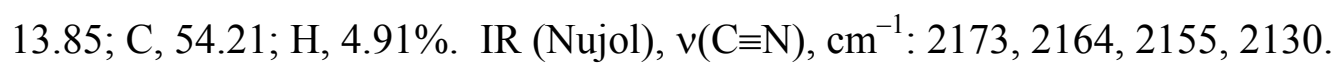

$\left[\mathbf{C r}(\mathbf{t m p h e n})_{2}\right]_{3}\left[\mathbf{C r}(\mathbf{C N})_{6}\right]_{2} \quad(5)$. The preparation was carried out anaerobically using conventional Schlenk techniques. A solution of $\left[(18 \text {-crown-6) } \mathrm{K}]_{3}\left[\mathrm{Cr}(\mathrm{CN})_{6}\right]\right.$ was prepared by stirring $150 \mathrm{mg}(0.451 \mathrm{mmol}) \mathrm{K}_{3}\left[\mathrm{Cr}(\mathrm{CN})_{6}\right]$ and $320 \mathrm{mg}(1.21 \mathrm{mmol})$ 18-crown-6 in $100 \mathrm{~mL}$ acetonitrile under $\mathrm{N}_{2}$ for $24 \mathrm{~h}$ and filtering the obtained solution to remove the excess of $\mathrm{K}_{3}\left[\mathrm{Cr}(\mathrm{CN})_{6}\right]$. The other solution was prepared by combining $14.0 \mathrm{mg}(0.020 \mathrm{mmol})$ $\mathrm{Cr}_{2}\left(\mathrm{O}_{2} \mathrm{CCF}_{3}\right)_{4} \cdot 2 \mathrm{THF}$ with $20.1 \mathrm{mg}(0.085 \mathrm{mmol})$ tmphen in $10 \mathrm{~mL}$ acetonitrile. After the 
mixture had been stirred under $\mathrm{N}_{2}$ for $30 \mathrm{~min}$, a clear brown solution was obtained. To this solution was quickly added $10 \mathrm{~mL}$ of the $\left[\mathrm{Cr}(\mathrm{CN})_{6}\right]^{3-}$ solution, and the mixture was left undisturbed for 3 days in an $\mathrm{N}_{2}$-filled dry box. After this period of time, dark brown needles formed at the bottom of the vial. They were filtered, washed with acetonitrile $(2 \times 20 \mathrm{~mL})$, and dried in vacuo. Yield - $10.1 \mathrm{mg}(35 \%)$. Elemental analysis indicated the presence of interstitial water molecules. Calcd. for $\mathrm{Cr}_{5} \mathrm{O}_{21} \mathrm{~N}_{24} \mathrm{C}_{108} \mathrm{H}_{138}\left(\mathbf{5} \cdot 21 \mathrm{H}_{2} \mathrm{O}\right): \mathrm{O}, 14.19 ; \mathrm{N}, 14.19 ; \mathrm{C}, 54.77 ; \mathrm{H}$,

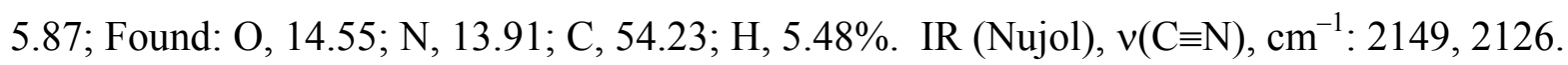

$\left[\operatorname{Mn}(\mathbf{t m p h e n})_{2}\right]_{3}\left[\mathbf{C r}(\mathbf{C N})_{6}\right]_{2}$ (6). A solution of $\left[(18 \text {-crown-6) } \mathrm{K}]_{3}\left[\mathrm{Cr}(\mathrm{CN})_{6}\right]\right.$ was prepared by stirring $151 \mathrm{mg}(0.464 \mathrm{mmol}) \mathrm{K}_{3}\left[\mathrm{Cr}(\mathrm{CN})_{6}\right]$ and $320 \mathrm{mg}(1.21 \mathrm{mmol})$ 18-crown-6 in $100 \mathrm{~mL}$ acetonitrile for $24 \mathrm{~h}$ and filtering the obtained solution to remove the excess of $\mathrm{K}_{3}\left[\mathrm{Cr}(\mathrm{CN})_{6}\right]$. The other solution was prepared by combining $14.5 \mathrm{mg}(0.040 \mathrm{mmol}) \mathrm{Mn}\left(\mathrm{ClO}_{4}\right)_{2} \cdot x \mathrm{H}_{2} \mathrm{O}(\mathrm{x} \approx 6)$ with $18.9 \mathrm{mg}(0.080 \mathrm{mmol})$ tmphen in $10 \mathrm{~mL}$ acetonitrile. After the mixture had been stirred for $30 \mathrm{~min}$, a clear pale yellow solution was obtained. To this solution was quickly added $10 \mathrm{~mL}$ of the $\left[\mathrm{Cr}(\mathrm{CN})_{6}\right]^{3-}$ solution. The mixture was left undisturbed for 3 days. After this period of time, clear pale yellow needle-like crystals formed at the bottom of the vial. They were filtered, washed with acetonitrile $(2 \times 20 \mathrm{~mL})$, and dried in vacuo. Yield - $9.9 \mathrm{mg}(33 \%)$. Elemental analysis indicated the presence of interstitial water molecules. Calcd. for $\mathrm{Mn}_{3} \mathrm{Cr}_{2} \mathrm{O}_{14} \mathrm{~N}_{24} \mathrm{C}_{108} \mathrm{H}_{124}$ $\left(6 \cdot 14 \mathrm{H}_{2} \mathrm{O}\right): \mathrm{O}, 9.95 ; \mathrm{N}, 14.93 ; \mathrm{C}, 57.62 ; \mathrm{H}, 5.55 ;$ Found: O, 10.26; N, 15.01; C, 57.70; H, 5.22\%. IR (Nujol), $v(\mathrm{C} \equiv \mathrm{N}), \mathrm{cm}^{-1}: 2153,2144,2127$.

\section{$\left[\mathrm{Co}(\text { tmphen })_{2}\right]_{3}\left[\mathrm{Cr}(\mathrm{CN})_{6}\right]_{2}(7)$.}

From acetonitrile (7a): An acetonitrile solution of $\left[(18 \text {-crown-6) } \mathrm{K}]_{3}\left[\mathrm{Cr}(\mathrm{CN})_{6}\right]\right.$ was prepared as described above for compound 6. The other solution was prepared by combining $11.6 \mathrm{mg}(0.040$ mmol) $\mathrm{Co}\left(\mathrm{NO}_{3}\right)_{2} \cdot 6 \mathrm{H}_{2} \mathrm{O}$ with $20.1 \mathrm{mg}(0.085 \mathrm{mmol})$ tmphen in $10 \mathrm{~mL}$ acetonitrile. After the mixture had been stirred for $30 \mathrm{~min}$, a clear orange solution was obtained. To this solution was quickly added $10 \mathrm{~mL}$ of the $\left[\mathrm{Cr}(\mathrm{CN})_{6}\right]^{3-}$ solution. The color of the mixture immediately changed to dark red. The mixture was left undisturbed for $24 \mathrm{~h}$. After this period of time, clear yellow needle-like crystals formed at the bottom of the vial. They were filtered, washed with acetonitrile $(2 \times 20 \mathrm{~mL})$, and dried in vacuo. Yield - $10.5 \mathrm{mg}(36 \%)$. Elemental analysis indicated the presence of interstitial water molecules. Calcd. for $\mathrm{Co}_{3} \mathrm{Cr}_{2} \mathrm{O}_{13} \mathrm{~N}_{24} \mathrm{C}_{108} \mathrm{H}_{122}$ $\left(7 \cdot 13 \mathrm{H}_{2} \mathrm{O}\right): \mathrm{O}, 9.26 ; \mathrm{N}, 14.97$;, 57.78; H, 5.48; Found: O, 9.48; N, 15.21; C, 58.01; H, 5.12\%.

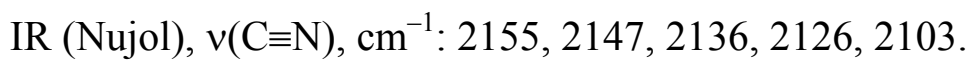


From methanol (7b): A solution of $\left[(18 \text {-crown-6)K }]_{3}\left[\mathrm{Cr}(\mathrm{CN})_{6}\right]\right.$ was prepared by stirring $151 \mathrm{mg}$ $(0.464 \mathrm{mmol}) \mathrm{K}_{3}\left[\mathrm{Cr}(\mathrm{CN})_{6}\right]$ and $320 \mathrm{mg}(1.21 \mathrm{mmol}) 18$-crown-6 in $100 \mathrm{~mL}$ methanol for $2 \mathrm{~h}$ and filtering the obtained solution to remove the excess of $\mathrm{K}_{3}\left[\mathrm{Cr}(\mathrm{CN})_{6}\right]$. The other solution was prepared by combining $9.6 \mathrm{mg}(0.040 \mathrm{mmol}) \mathrm{CoCl}_{2} \cdot 6 \mathrm{H}_{2} \mathrm{O}$ with $20.1 \mathrm{mg}(0.085 \mathrm{mmol})$ tmphen in $10 \mathrm{~mL}$ methanol. After the mixture had been stirred for $30 \mathrm{~min}$, a clear yellow solution was obtained. To this solution was quickly added $10 \mathrm{~mL}$ of the $\left[\mathrm{Cr}(\mathrm{CN})_{6}\right]^{3-}$ solution, causing immediate precipitation of peach powder. The mixture was stirred for $5 \mathrm{~min}$, and the product was separated by filtration, washed with methanol $(2 \times 20 \mathrm{~mL})$, and dried in vacuo. Yield -11.6 $\mathrm{mg}(39 \%)$. Elemental analysis indicated the presence of interstitial water molecules. Calcd. for $\mathrm{Co}_{3} \mathrm{Cr}_{2} \mathrm{O}_{18} \mathrm{~N}_{24} \mathrm{C}_{108} \mathrm{H}_{132}\left(7 \cdot 18 \mathrm{H}_{2} \mathrm{O}\right): \mathrm{O}, 12.33 ; \mathrm{N}, 14.40 ; \mathrm{C}, 55.55 ; \mathrm{H}, 5.70$; Found: O, 12.59; N, 14.27; C, 55.58; H, 5.43\%. IR (Nujol), $v(\mathrm{C} \equiv \mathrm{N}), \mathrm{cm}^{-1}: 2156,2127$.

$\left[\mathbf{N i}(\text { tmphen })_{2}\right]_{3}\left[\mathrm{Cr}(\mathbf{C N})_{6}\right]_{2}$ (8). A methanol solution of $\left[(18 \text {-crown-6) } \mathrm{K}]_{3}\left[\mathrm{Cr}(\mathrm{CN})_{6}\right]\right.$ was prepared as described above for compound 7a. The other solution was prepared by combining $10.0 \mathrm{mg}(0.040 \mathrm{mmol}) \mathrm{Ni}(\mathrm{OAc})_{2} \cdot 6 \mathrm{H}_{2} \mathrm{O}$ with $20.1 \mathrm{mg}(0.085 \mathrm{mmol})$ tmphen in $10 \mathrm{~mL}$ methanol. After the mixture had been stirred for $30 \mathrm{~min}$, a clear purple solution was obtained. To this solution was quickly added $10 \mathrm{~mL}$ of the $\left[\mathrm{Co}(\mathrm{CN})_{6}\right]^{3-}$ solution, and the mixture was left undisturbed for 14 days. After this period of time, pink needle-like crystals formed at the bottom of the vial. They were filtered, washed with methanol $(2 \times 20 \mathrm{~mL})$, and dried in vacuo. Yield $10.1 \mathrm{mg}(34 \%)$. Elemental analysis indicated the presence of interstitial water molecules. Calcd. for $\mathrm{Ni}_{3} \mathrm{Cr}_{2} \mathrm{O}_{12} \mathrm{~N}_{24} \mathrm{C}_{108} \mathrm{H}_{120}\left(8 \cdot 12 \mathrm{H}_{2} \mathrm{O}\right)$ : O, 8.62; N, 15.09; C, 58.25; H, 5.43; Found: O, 8.51; N, 14.73; C, 58.81; H, 5.46\%. IR (Nujol), $v(\mathrm{C} \equiv \mathrm{N}), \mathrm{cm}^{-1}: 2160,2150,2127$.

$\left[\mathbf{M n}(\mathbf{t m p h e n})_{2}\right]_{3}\left[\mathbf{F e}(\mathbf{C N})_{6}\right]_{2}(\mathbf{9}) .9 .9 \mathrm{mg}(0.040 \mathrm{mmol}) \mathrm{Mn}(\mathrm{OAc})_{2} \cdot 4 \mathrm{H}_{2} \mathrm{O}$ and $18.9 \mathrm{mg}(0.080$ mmol) tmphen were combined in $10 \mathrm{~mL}$ acetonitrile. After the mixture had been stirred for 30 min, a clear pale yellow solution was obtained. To this solution was quickly added a solution of $37.6 \mathrm{mg}(0.040 \mathrm{mmol})(\mathrm{TBA})_{3}\left[\mathrm{Fe}(\mathrm{CN})_{6}\right]$ in $10 \mathrm{~mL}$ acetonitrile. The mixture was left undisturbed for 2 days. After this period of time, yellow-brown needle-like crystals formed at the bottom of the vial. They were filtered, washed with acetonitrile $(2 \times 20 \mathrm{~mL})$, and dried in vacuo. Yield $-9.5 \mathrm{mg}(32 \%)$. Elemental analysis indicated the presence of interstitial water molecules. Calcd. for $\mathrm{Mn}_{3} \mathrm{Fe}_{2} \mathrm{O}_{12} \mathrm{~N}_{24} \mathrm{C}_{108} \mathrm{H}_{120}\left(9 \cdot 12 \mathrm{H}_{2} \mathrm{O}\right): \mathrm{O}, 8.67 ; \mathrm{N}, 15.18 ; \mathrm{C}, 58.56 ; \mathrm{H}, 5.46$; Found: O, 8.61; N, 14.90; C, 57.92; H, 5.35\%. IR (Nujol), $v(\mathrm{C} \equiv \mathrm{N}), \mathrm{cm}^{-1}: 2147,2141,2135$, $2117,2112$. 
(a)

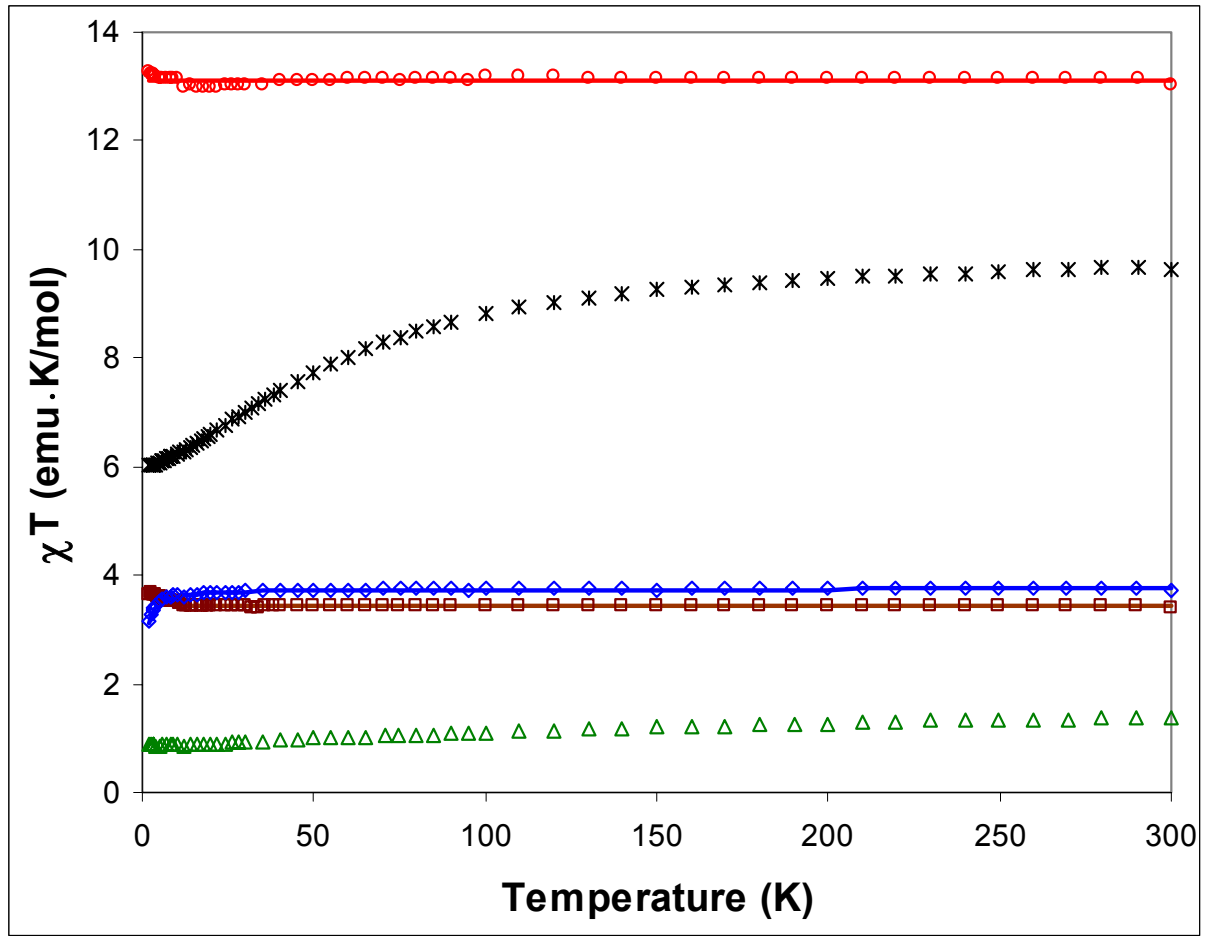

(b)

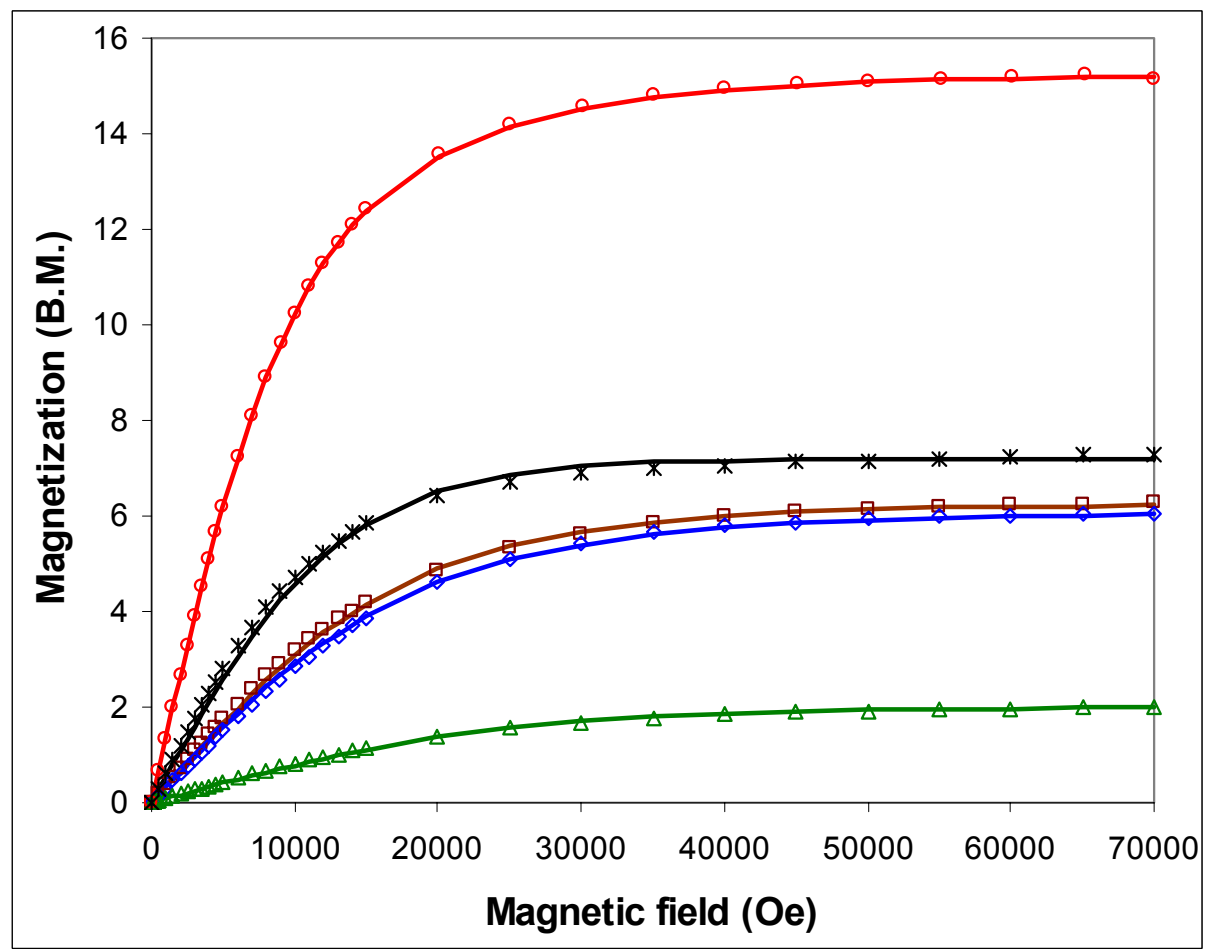

Figure S1. (a) Temperature dependence of the $\chi T$ product for $\mathbf{1}$ (red), $\mathbf{2}$ (black), $\mathbf{3}$ (brown), $\mathbf{1 0}$ (blue), and 11 (green). The solid lines correspond to the Curie-Weiss law. (b) Field dependence of magnetization for $\mathbf{1}$ (red), $\mathbf{2}$ (black), $\mathbf{3}$ (brown), $\mathbf{1 0}$ (blue), and $\mathbf{1 1}$ (green) measured at $1.8 \mathrm{~K}$. The solid lines correspond to the best fit to the Brillouin functions. 
(a)

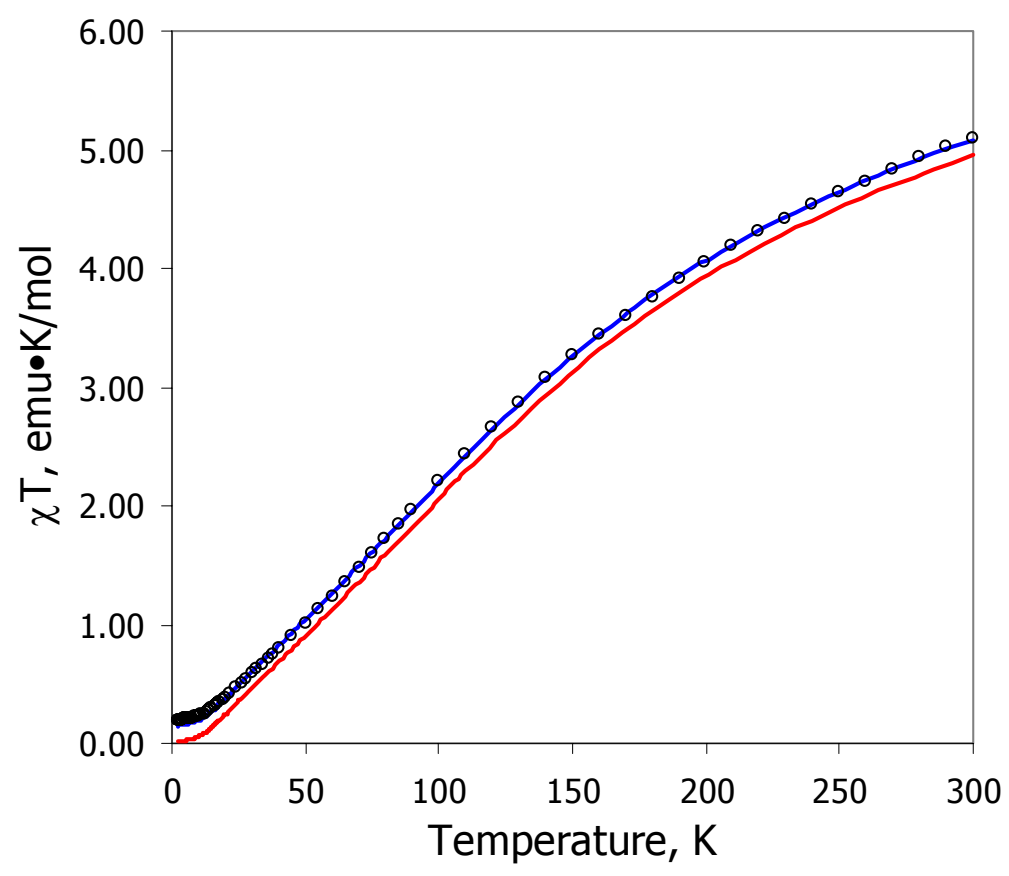

(b)

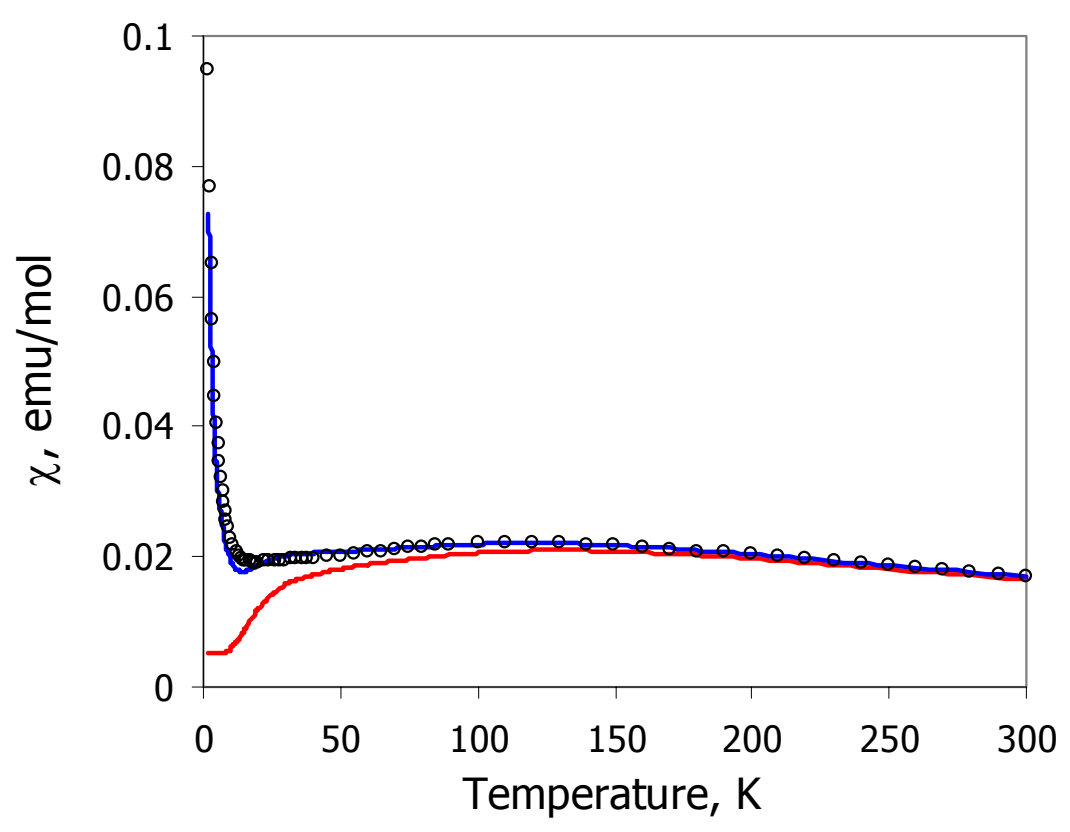

Figure S2. (a) Temperature dependence of the $\chi T$ product for 5. (b) Temperature dependence of the magnetic susceptibility $\chi$ for $\mathbf{5}$. The solid lines represent theoretical simulation with (blue) or without (red) $\mathrm{Cr}^{\mathrm{II}}$ paramagnetic impurity $\left(g_{\mathrm{Cr}^{\prime}}=2.00, g_{\mathrm{Cr}}=2.32, J=-21.0 \mathrm{~cm}^{-1}\right)$. 


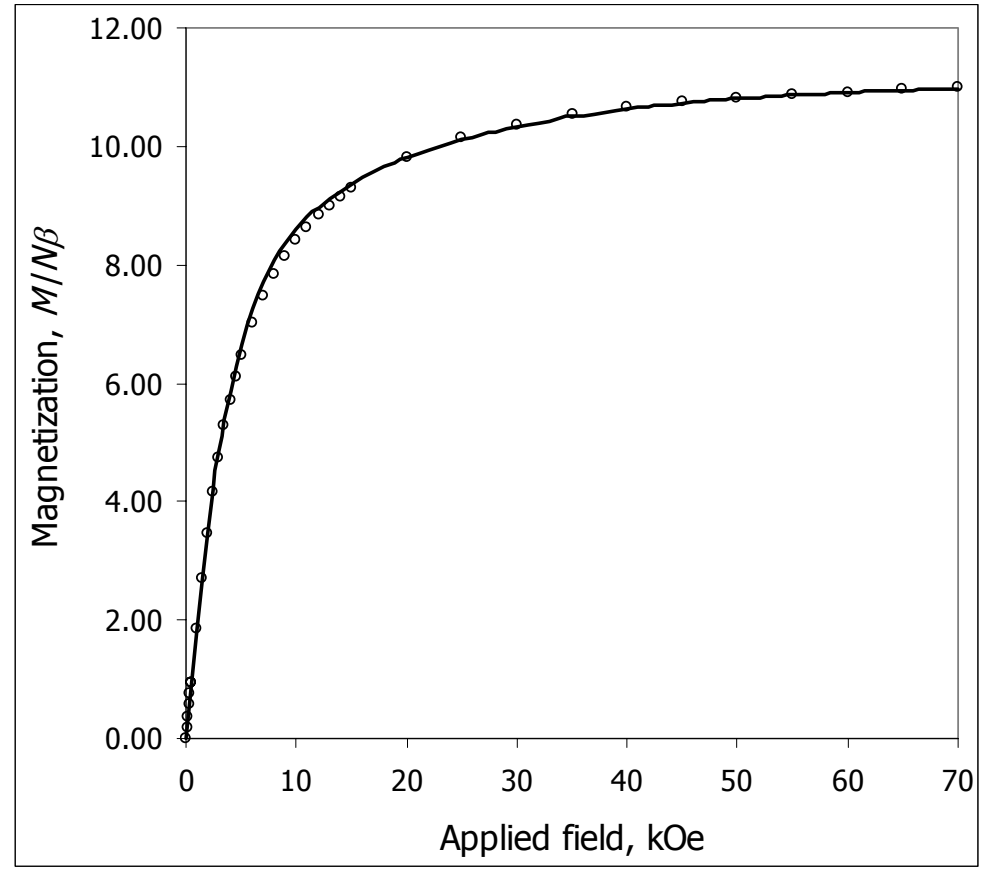

Figure S3. Magnetization $v s$ applied field for sample 7b. The solid line represents the theoretical fit to the Brillouin function of $S=9 / 2$, with $g=2.48$ and $D=0.52 \mathrm{~cm}^{-1}$.

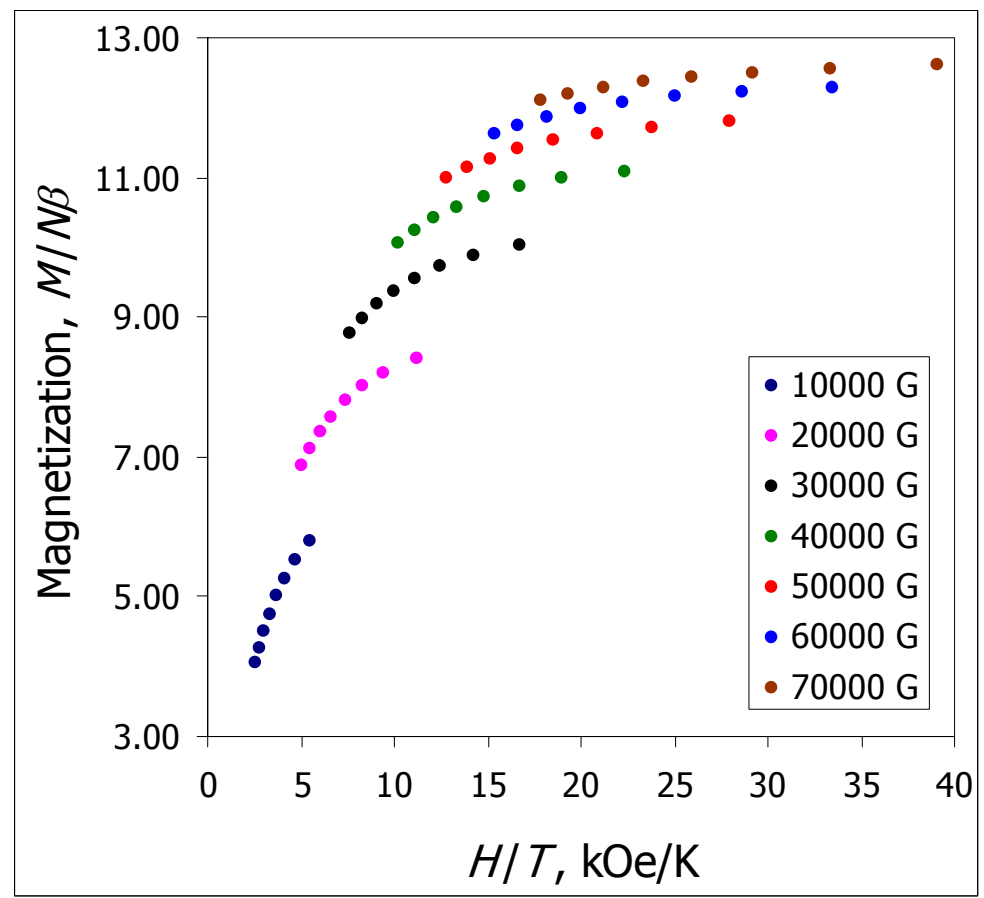

Figure S4. Reduced magnetization for compound 9. 


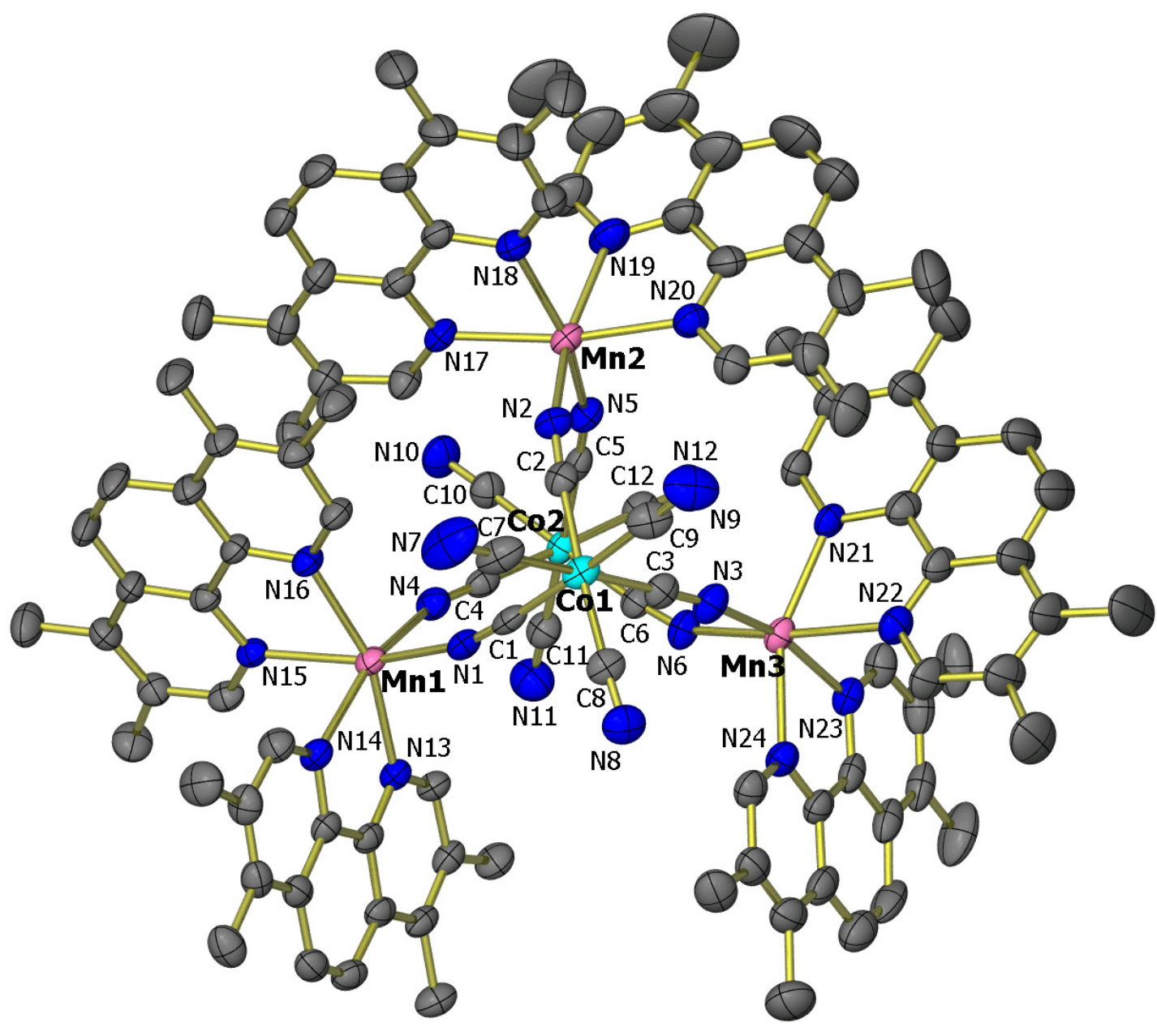

Figure S5. Thermal ellipsoid plot of 1 (50\% probability level; $\mathrm{H}$ atoms are omitted for clarity). 


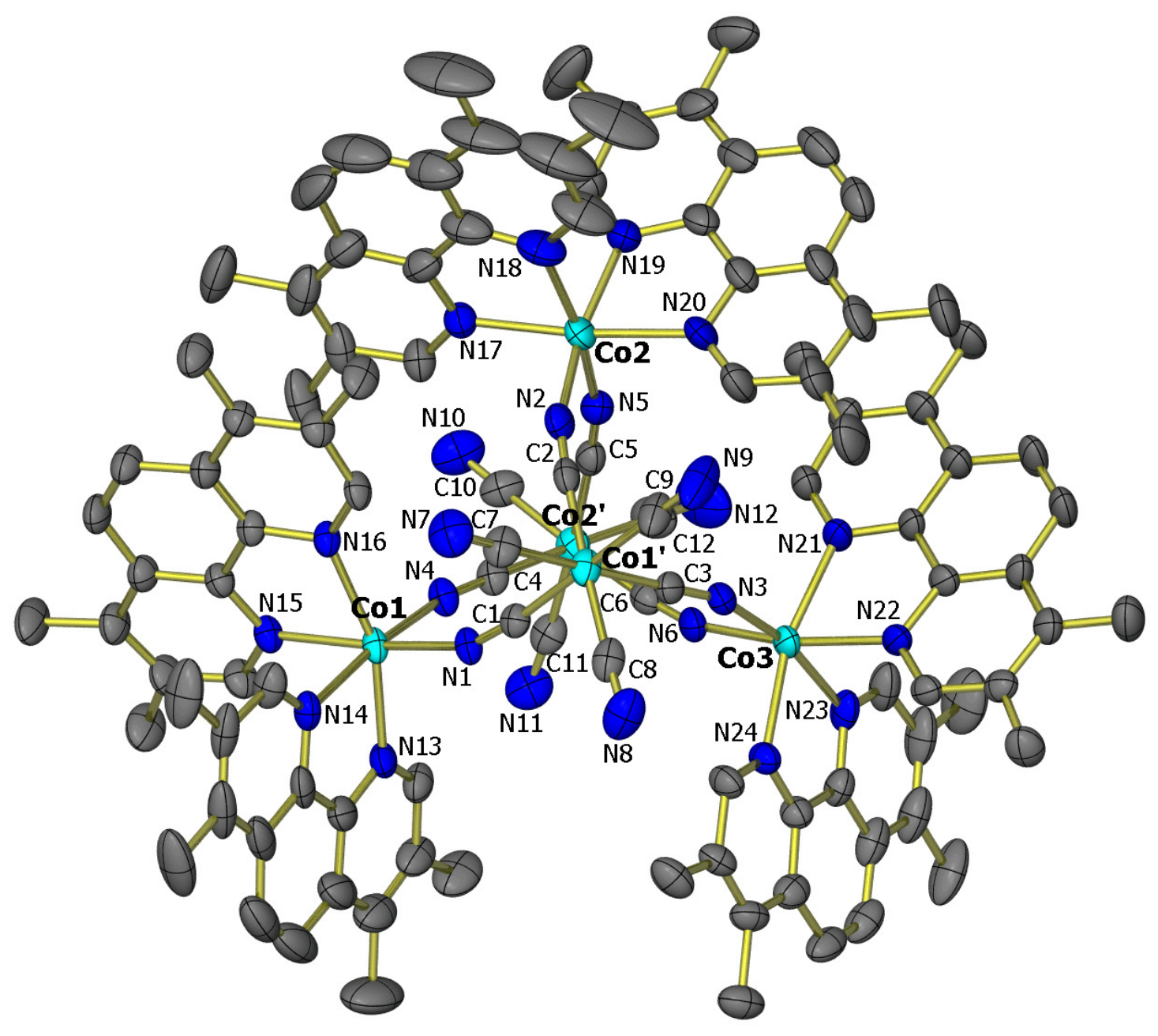

Figure S6. Thermal ellipsoid plot of 2 (50\% probability level; $\mathrm{H}$ atoms and solvent molecules are omitted for clarity). 


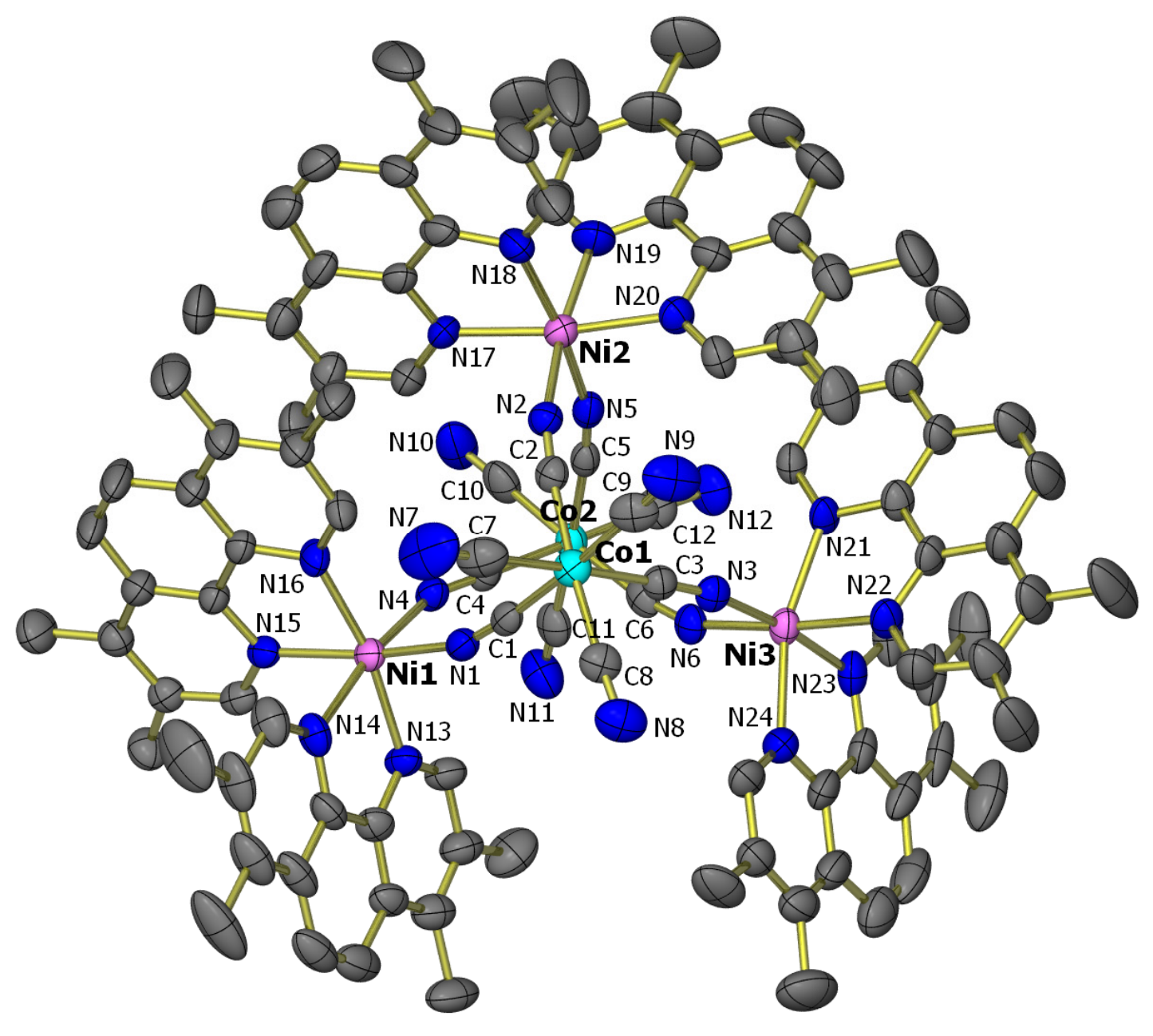

Figure S7. Thermal ellipsoid plot of $\mathbf{3}$ (50\% probability level; H atoms are omitted for clarity). 


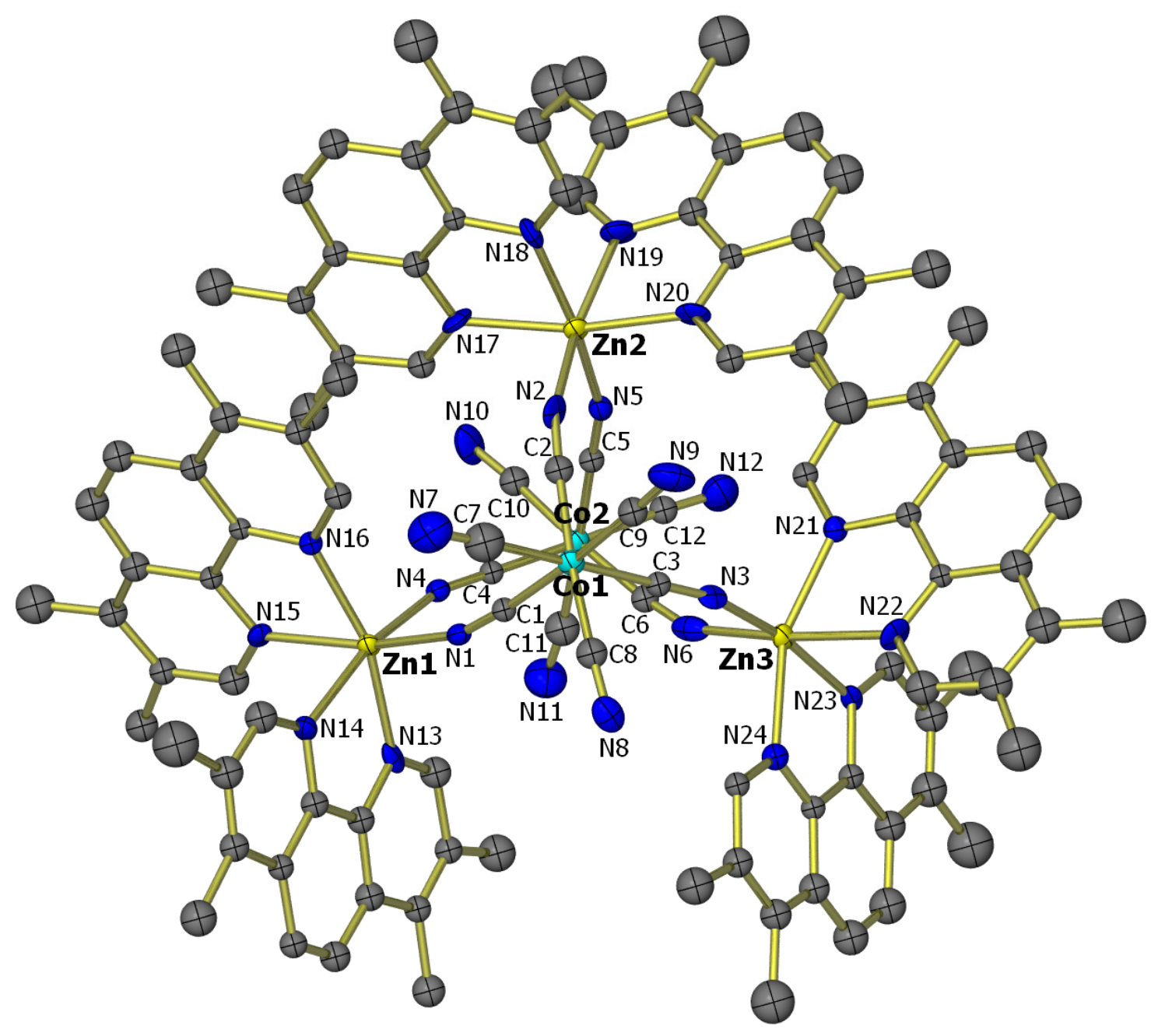

Figure S8. Thermal ellipsoid plot of 4 (50\% probability level; $\mathrm{H}$ atoms are omitted for clarity). 


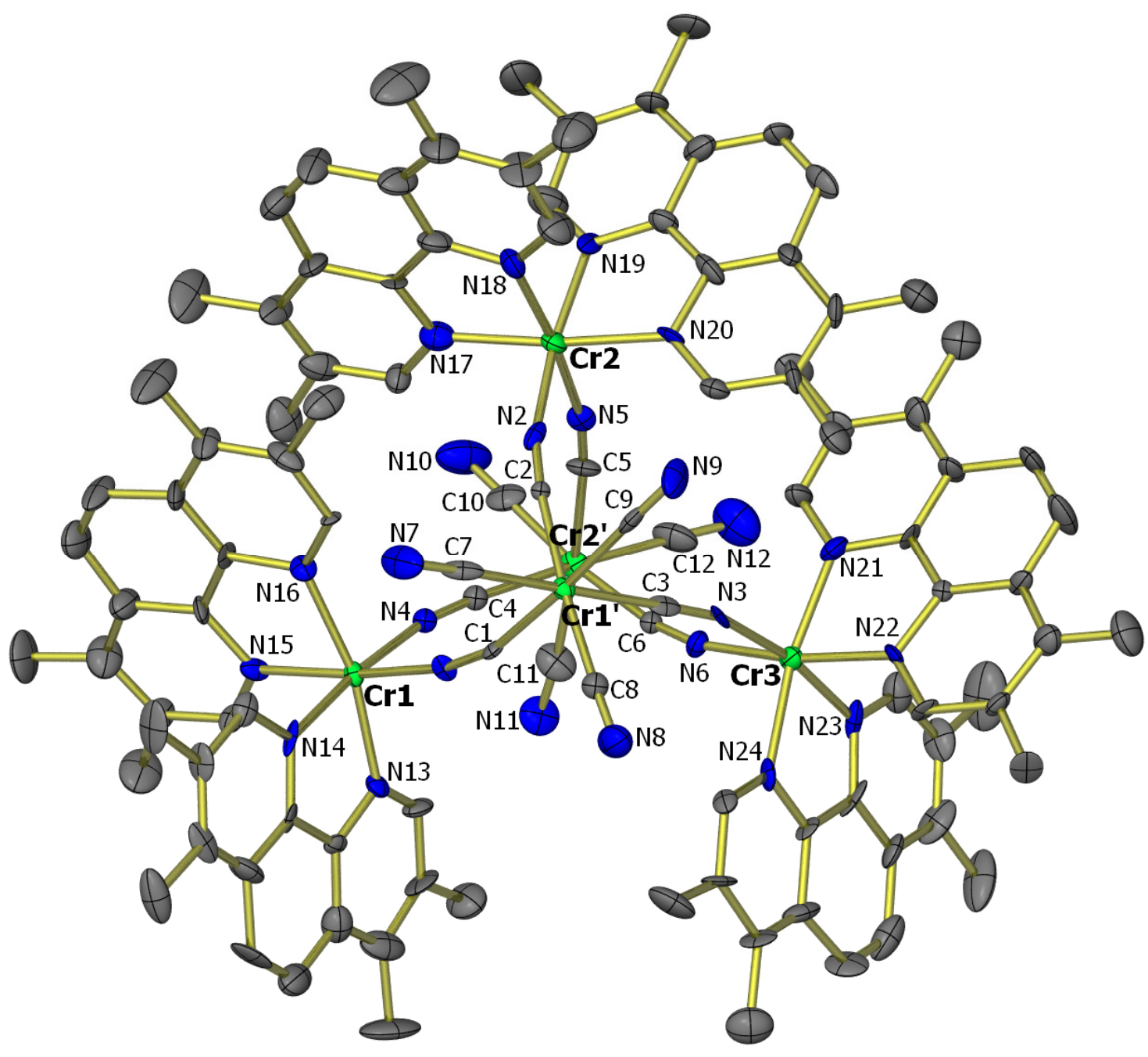

Figure S9. Thermal ellipsoid plot of 5 (50\% probability level; $\mathrm{H}$ atoms are omitted for clarity). 


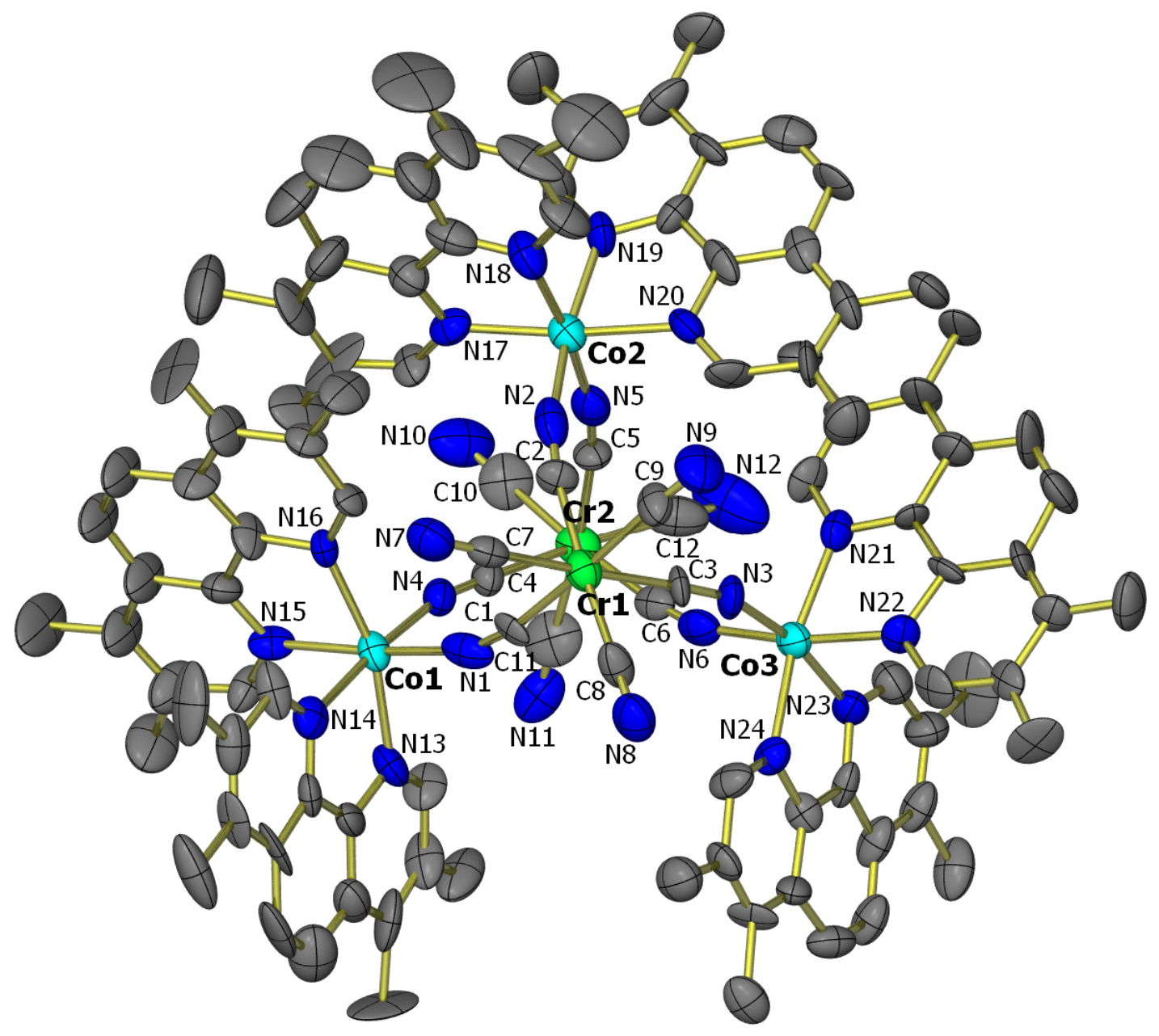

Figure S10. Thermal ellipsoid plot of 7 (50\% probability level; $\mathrm{H}$ atoms are omitted for clarity). 


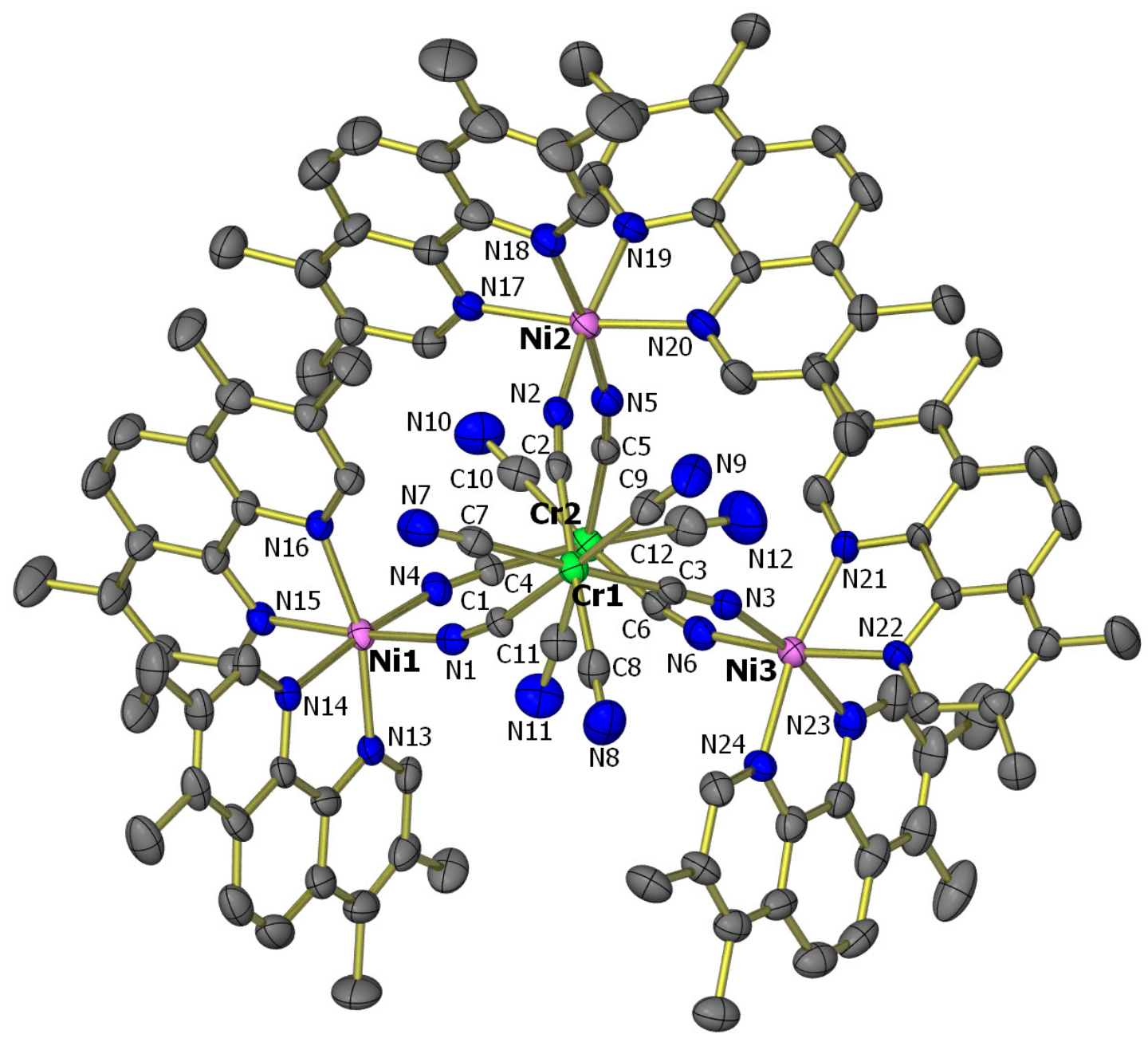

Figure S11. Thermal ellipsoid plot of 8 (50\% probability level; $\mathrm{H}$ atoms are omitted for clarity). 


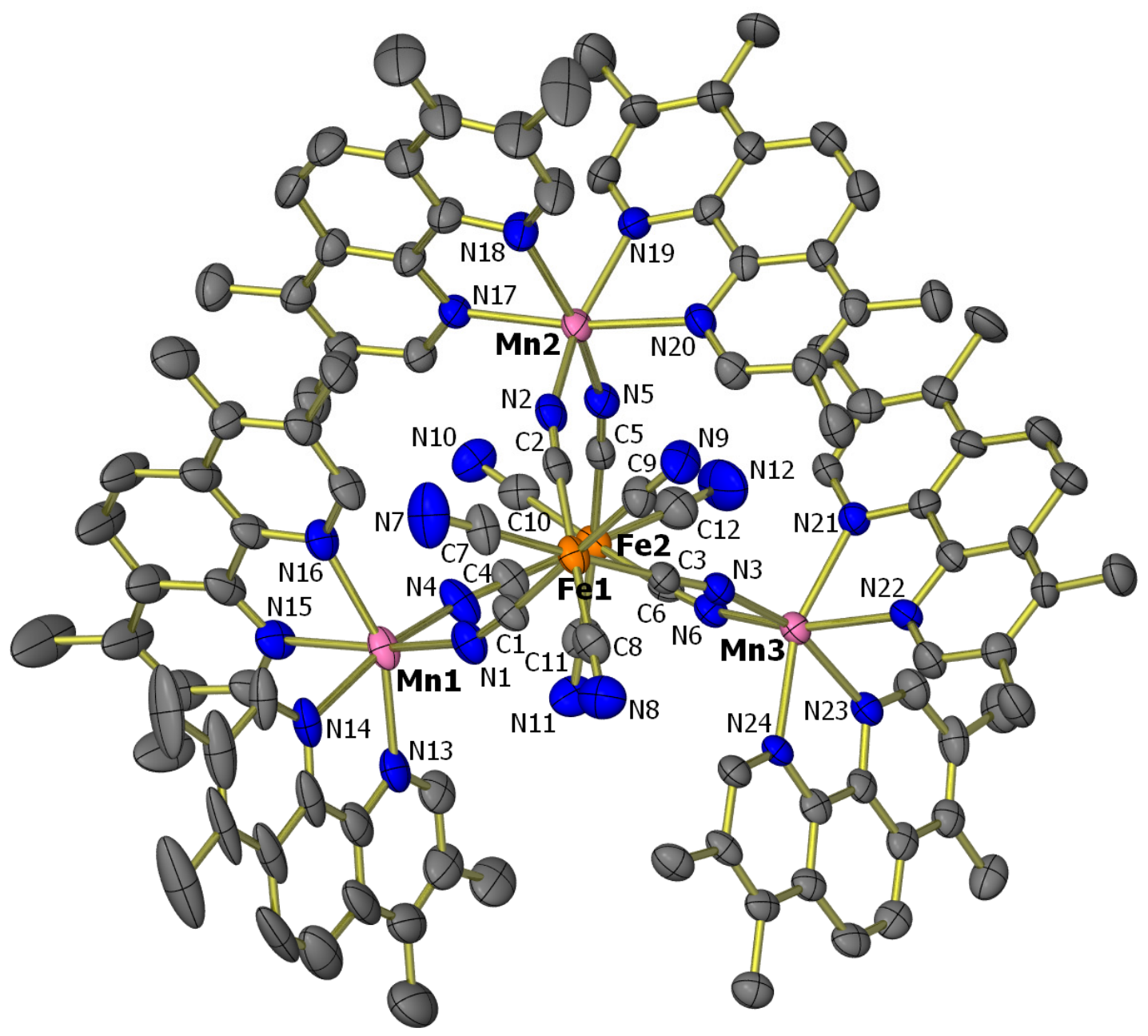

Figure S12. Thermal ellipsoid plot of 9 (50\% probability level; $\mathrm{H}$ atoms and solvent molecules are omitted for clarity). 
Table S1. Metal-to-ligand bond distances $(\AA)$ in the crystal structures of compounds 1-9. ${ }^{a}$

\begin{tabular}{cccccc}
\hline \multirow{2}{*}{ Compound } & \multicolumn{3}{c}{ Equatorial } & \multicolumn{2}{c}{ Axial } \\
\cline { 2 - 6 } & $\mathrm{M} 1-\mathrm{N}$ & $\mathrm{M} 2-\mathrm{N}$ & $\mathrm{M} 3-\mathrm{N}$ & $\mathrm{M}^{\prime} 1-\mathrm{C}$ & $\mathrm{M}^{\prime} 2-\mathrm{C}$ \\
\hline \multirow{3}{*}{$\mathbf{1}\left(\mathrm{Mn}_{3} \mathrm{Co}_{2}\right)$} & $2.154(2)$ & $2.154(2)$ & $2.146(2)$ & $1.883(3)$ & $1.885(3)$ \\
& $2.179(2)$ & $2.161(2)$ & $2.183(2)$ & $1.895(3)$ & $1.896(3)$ \\
& $2.269(2)$ & $2.255(2)$ & $2.248(2)$ & $1.900(3)$ & $1.897(3)$ \\
& $2.277(2)$ & $2.266(2)$ & $2.251(2)$ & $1.894(3)$ & $1.884(3)$ \\
& $2.286(2)$ & $2.276(3)$ & $2.274(2)$ & $1.897(3)$ & $1.898(3)$ \\
& $2.306(2)$ & $2.284(2)$ & $2.296(2)$ & $1.899(3)$ & $1.901(3)$ \\
\hline \multirow{2}{*}{$\left(\mathrm{Co}_{3} \mathrm{Co}_{2}\right)$} & $2.052(5)$ & $2.074(6)$ & $2.057(5)$ & $1.883(6)$ & $1.888(6)$ \\
& $2.098(4)$ & $2.088(6)$ & $2.104(5)$ & $1.894(7)$ & $1.900(7)$ \\
& $2.131(5)$ & $2.135(6)$ & $2.145(5)$ & $1.905(6)$ & $1.902(7)$ \\
& $2.149(5)$ & $2.142(5)$ & $2.148(5)$ & $1.882(6)$ & $1.883(7)$ \\
& $2.153(4)$ & $2.144(5)$ & $2.163(5)$ & $1.894(6)$ & $1.903(7)$ \\
$\mathbf{3}\left(\mathrm{Ni}_{3} \mathrm{Co}_{2}\right)$ & $2.164(4)$ & $2.156(5)$ & $2.167(5)$ & $1.906(7)$ & $1.904(7)$ \\
& $2.030(4)$ & $2.064(4)$ & $2.024(4)$ & $1.880(5)$ & $1.878(5)$ \\
& $2.071(4)$ & $2.065(4)$ & $2.074(4)$ & $1.902(5)$ & $1.894(5)$ \\
& $2.090(4)$ & $2.079(4)$ & $2.081(4)$ & $1.905(5)$ & $1.904(6)$ \\
& $2.097(4)$ & $2.089(4)$ & $2.092(4)$ & $1.893(5)$ & $1.891(6)$ \\
& $2.108(4)$ & $2.103(4)$ & $2.093(4)$ & $1.889(6)$ & $1.891(6)$ \\
& $2.124(4)$ & $2.105(4)$ & $2.108(4)$ & $1.919(6)$ & $1.906(5)$ \\
\hline \multirow{4}{*}{$\mathbf{4}\left(\mathrm{Zn}_{3} \mathrm{Co}_{2}\right)$} & $2.065(5)$ & $2.070(4)$ & $2.071(6)$ & $1.867(6)$ & $1.841(6)$ \\
& $2.114(5)$ & $2.093(6)$ & $2.127(5)$ & $1.876(7)$ & $1.845(7)$ \\
& $2.183(5)$ & $2.131(5)$ & $2.136(6)$ & $1.882(7)$ & $1.887(7)$ \\
& $2.184(5)$ & $2.141(5)$ & $2.148(5)$ & $1.811(7)$ & $1.876(7)$ \\
& $2.193(5)$ & $2.196(6)$ & $2.191(6)$ & $1.842(7)$ & $1.881(7)$ \\
& $2.210(5)$ & $2.206(6)$ & $2.268(5)$ & $1.88(1)$ & $1.939(8)$ \\
\hline
\end{tabular}

${ }^{a}$ Bonds to the cyanide ligands are highlighted in yellow. 
Table S1 (cont.). Metal-to-ligand bond distances $(\AA)$ in the crystal structures of compounds $1-9 .{ }^{a}$

\begin{tabular}{|c|c|c|c|c|c|}
\hline \multirow{2}{*}{ Compound } & \multicolumn{3}{|c|}{ Equatorial } & \multicolumn{2}{|c|}{ Axial } \\
\hline & $\mathrm{M} 1-\mathrm{N}$ & $\mathrm{M} 2-\mathrm{N}$ & M3-N & $\mathrm{M}^{\prime} 1-\mathrm{C}$ & $\mathrm{M}^{\prime} 2-\mathrm{C}$ \\
\hline \multirow{6}{*}{$5\left(\mathrm{Cr}_{3} \mathrm{Cr}_{2}\right)$} & $2.005(9)$ & $2.003(9)$ & $2.003(9)$ & $2.06(1)$ & $2.09(1)$ \\
\hline & $2.006(8)$ & $2.01(1)$ & $2.020(9)$ & $2.05(1)$ & $2.09(1)$ \\
\hline & $2.002(9)$ & $2.02(1)$ & $2.013(9)$ & $2.08(1)$ & $2.09(1)$ \\
\hline & $2.034(8)$ & $2.033(9)$ & $2.026(9)$ & $2.02(1)$ & $2.02(1)$ \\
\hline & $2.041(9)$ & $2.04(1)$ & $2.054(9)$ & $2.04(1)$ & $2.03(1)$ \\
\hline & $2.076(9)$ & $2.05(1)$ & $2.072(9)$ & $2.07(1)$ & $2.05(1)$ \\
\hline \multirow{6}{*}{$7\left(\mathrm{Co}_{3} \mathrm{Cr}_{2}\right)$} & $2.026(9)$ & $2.04(1)$ & $2.02(1)$ & $2.00(1)$ & $2.00(1)$ \\
\hline & $2.08(1)$ & $2.07(1)$ & $2.05(1)$ & $2.03(1)$ & $2.06(1)$ \\
\hline & $2.111(9)$ & $2.07(1)$ & $2.092(9)$ & $2.10(1)$ & $2.10(1)$ \\
\hline & $2.114(9)$ & $2.09(1)$ & $2.093(9)$ & $2.06(1)$ & $2.00(2)$ \\
\hline & $2.12(1)$ & $2.11(1)$ & $2.139(9)$ & $2.07(1)$ & $2.03(2)$ \\
\hline & $2.14(1)$ & $2.140(9)$ & $2.14(1)$ & $2.09(1)$ & $2.14(2)$ \\
\hline \multirow{6}{*}{$8\left(\mathrm{Ni}_{3} \mathrm{Cr}_{2}\right)$} & $2.028(2)$ & $2.046(2)$ & $2.032(2)$ & $2.057(2)$ & $2.047(2)$ \\
\hline & $2.070(2)$ & $2.056(2)$ & $2.050(2)$ & $2.065(2)$ & $2.056(2)$ \\
\hline & $2.084(2)$ & $2.085(2)$ & $2.087(2)$ & $2.066(2)$ & $2.064(2)$ \\
\hline & $2.088(2)$ & $2.088(2)$ & $2.100(2)$ & $2.062(2)$ & $2.061(3)$ \\
\hline & $2.095(2)$ & $2.089(2)$ & $2.101(2)$ & $2.071(2)$ & $2.062(2)$ \\
\hline & $2.103(2)$ & $2.105(2)$ & $2.103(2)$ & $2.078(2)$ & $2.074(2)$ \\
\hline \multirow{6}{*}{$9\left(\mathrm{Mn}_{3} \mathrm{Fe}_{2}\right)$} & $2.126(8)$ & $2.158(7)$ & $2.140(8)$ & $1.909(9)$ & $1.918(9)$ \\
\hline & $2.177(7)$ & $2.166(8)$ & $2.184(7)$ & $1.918(9)$ & $1.920(9)$ \\
\hline & $2.245(7)$ & $2.259(6)$ & $2.264(6)$ & $1.923(8)$ & $1.922(8)$ \\
\hline & $2.258(8)$ & $2.268(7)$ & $2.281(7)$ & $1.91(1)$ & $1.93(1)$ \\
\hline & $2.263(8)$ & $2.268(7)$ & $2.281(6)$ & $1.926(9)$ & $1.931(9)$ \\
\hline & $2.281(7)$ & $2.287(7)$ & $2.301(7)$ & $1.93(1)$ & $1.943(9)$ \\
\hline
\end{tabular}

${ }^{a}$ Bonds to the cyanide ligands are highlighted in yellow. 